\title{
Efficacy and safety of different doses of a slow-release corticosteroid implant for macular edema [Corrigendum]
}

Liu QY, He MM, Shi H, et al. Drug Des Devel Ther. 2015;9: $2527-2535$.

In "Efficacy and safety of different doses of a slow release corticosteroid implant for macular edema: meta-analysis of randomized controlled trials" published May 2015, on page 2530, in Table 1 we have mistakenly stated the fluocinolone acetonide (FA) intravitreal inserts as Retisert ${ }^{\circledR}$ in the Campochiaro et al study; they were in fact the fluocinolone acetonide intravitreal inserts. We feel sorry about that, and we will be more rigorous to avoid any unnecessary confusion in the future.

\section{Publish your work in this journal}

Drug Design, Development and Therapy is an international, peerreviewed open-access journal that spans the spectrum of drug design and development through to clinical applications. Clinical outcomes, patient safety, and programs for the development and effective, safe, and sustained use of medicines are a feature of the journal, which has also been accepted for indexing on PubMed Central. The manuscript management system is completely online and includes a very quick and fair peer-review system, which is all easy to use. Visit http://www.dovepress.com/testimonials.php to read real quotes from published authors. 